\title{
Carbon isotope and magnetic polarity evidence for non- depositional events within the Cambrian-Ordovician Boundary section near Dayangcha, Jilin Province, China
}

\author{
R. L. RIPPERDAN*, M. MAGARITZ* \& J. L. KIRSCHVINK†
}

* Department of Environmental Science and Energy Research, Weizmann Institute of Science, Rehovot 76-100, Israel $\dagger$ Division of Geological and Planetary Sciences, California Institute of Technology, Pasadena, California 91125, U.S.A.

(Received 4 August 1992; accepted 11 February 1993)

\begin{abstract}
Carbon isotope and magnetic polarity stratigraphic results from the Cambrian-Ordovician Boundary section at Xiaoyangqiao, near Dayangcha, Jilin Province, China, in comparison to a contemporaneous section at Black Mountain, Australia, indicate strata equivalent to major portions of the Australian sequence are either absent or are restricted to highly condensed intervals. These intervals are correlative with regressive sea level events identified in Australia and western North America, suggesting regional or eustatic sea level changes strongly influenced deposition of the Xiaoyangqiao sequence. These results also suggest the Xiaoyangqiao section is unfavourable as the site of the Cambrian-Ordovician Boundary Global Stratotype Section and Point.
\end{abstract}

\section{Introduction}

Definition of a Global Stratotype Section and Point (GSSP) for the Cambrian-Ordovician Boundary by an International Commission on Stratigraphy Working Group has been hampered in part by concerns about the stratigraphic completeness of the Xiaoyangqiao Critical Section, near Dayangcha, Jilin Province, China. Objections have been voiced because of disagreements over the stratigraphic level for the first appearance datum (FAD) of the conodont species Cordylodus lindstromi, a level favoured because of its proximity to the first influx of nematophorous graptolites and widespread occurrence in continental platform and slope facies, and because of the presence of conglomeratic units near the FAD of $C$. lindstromi, raising concerns that hiatuses may exist within the candidate section. Although problems in determining a precise FAD for $C$. lindstromi arising from taxonomic uncertainty have largely been redressed (Nicoll, 1990, 1991, 1992), determination of the stratigraphic completeness of the section continues to be a source of difficulty because of the limitations of biostratigraphic techniques for resolving such problems.

Simultaneous correlation of carbon isotope and geomagnetic polarity reversals provides a correlation framework that can be used independently to refine fossil-based temporal correlations and to assess more accurately stratigraphic completeness. The polarity of the geomagnetic field has the same value simultaneously over the entire Earth's surface, except during geologically very brief periods $(<10 \mathrm{ka})$ of polarity reversal (Harrison \& Somayajulu, 1966; Opdyke, Kent \& Lowrie, 1973; others), allowing polarity zonations within different depositional environments to be correlated in 'real time' with high accuracy when properly constrained by other stratigraphic methods. Also, magnetic polarity is a property of the Earth's deep interior and is therefore not sensitive to sedimentary or environmental changes at the surface. Variations in marine inorganic carbon isotopic ratios are found throughout the geological record (Wadleigh \& Veizer, 1992; many others), and provide a means for overcoming the non-uniqueness imposed by the binary nature of the polarity reversal record. Major shifts in carbon rations take place rapidly and seem to have global significance (e.g. Zachos \& Arthur, 1986; Margolis et al. 1987; Magaritz, 1989). Local changes in $\delta^{13} \mathrm{C}$ appear to reflect accurately changes in global $\delta^{13} \mathrm{C}$ because of the very rapid oceanic mixing rate of carbon dioxide (Holland, 1978; Kump \& Garrels 1986), making $\delta^{13} \mathrm{C}$ variation a useful stratigraphic marker despite differences in the absolute value of local $\delta^{13} \mathrm{C}$. Also, $\delta^{13} \mathrm{C}$ values are relatively insensitive to many postdepositional processes because of the extremely low abundance of carbon in pore solutions relative to carbonate rock (Magaritz, 1983; Banner \& Hanson, 1990).

We present here new carbon isotope results from the GSSP-candidate Cambrian-Ordovician boundary section at Xiaoyangqiao, China. These results, in combination with existing magnetic polarity data (R. L. Ripperdan, unpub. Ph.D. thesis, Cal. Inst. Tech., 1990) and biostratigraphic information (Chen et al. 1988), have been used to assess the stratigraphic continuity of the section. The simultaneous occurrences of polarity reversals, sharp changes in the $\delta^{13} \mathrm{C}$ profile, and biostratigraphic boundaries within the Xiaoyangqiao section strongly suggest underlying 

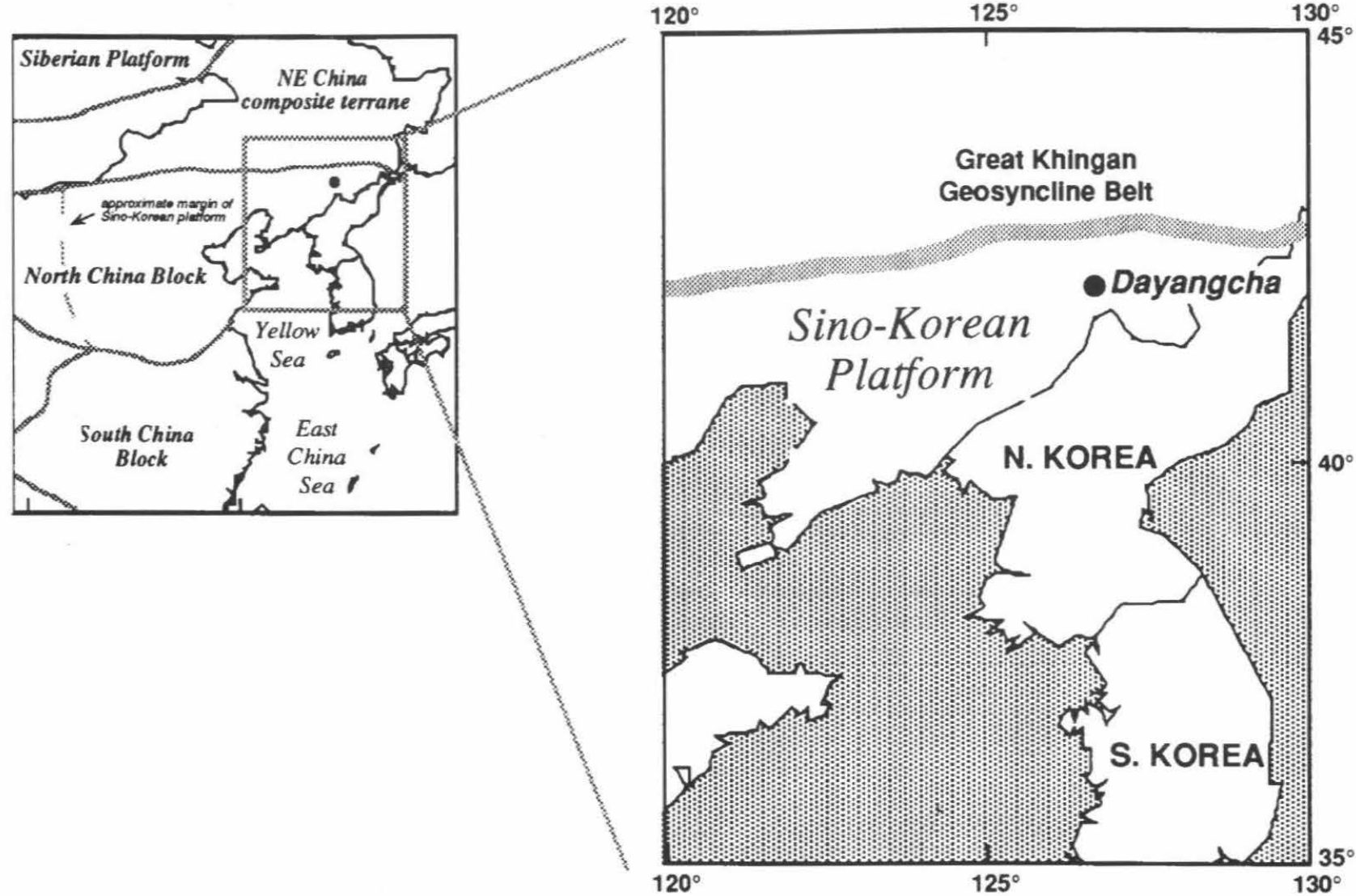

Figure 1. Generalized location map for the Dayangcha area, northeast China. (See Chen et al. 1988 for detailed index maps.)

hiatuses or intervals of extremely low depositional rates. We then correlate these results to those from the contemporaneous section at Black Mountain, western Queensland, Australia, and show that these intervals correlate to previously identified regressive sea level events within the Australian sequence and in the western United States.

\section{Geologic setting}

The sections at Xiaoyangqiao, near Dayangcha, in Jilin province, northeastern China, have become internationally prominent from their status as a candidate for placement of the Cambrian-Ordovician boundary Global Stratotype Section and Point (GSSP). The Xiaoyangqiao Critical Section (XCS) is the middle of three overlapping segments spanning the Proconodontus tenuiserratus to Cordylodus angulatus zones ( $10 \mathrm{Ma}$; Harland et al. 1990), and contains the base of the Cordylodus lindstromi Zone, the level currently most favoured for placement of the boundary GSSP.

The sections lie within the Changbaishan Mountains near the northern margin of the Sino-Korean Platform (Fig. 1). They consist of rhythmical finegrained carbonates, with intermittent clastic deposits superimposed upon the primary periodic sequence, and were deposited in moderately deep water along the outer shelf of the platform (Chen et al. 1988). Exposures are found in steep stream banks, are relatively fresh, and dip uniformly $30^{\circ}$ to the southsoutheast with no obvious faulting or folding. A conodont alteration index value of 1.5 (Chen et al. 1988) suggests the area has not been subjected to appreciable thermal metamorphism or been deeply buried (Epstein, Epstein \& Harris, 1977).

Detailed biostratigraphic zonations have been established for conodonts and trilobites, and a number of other groups have been studied, including graptolites and acritarchs (see Chen et al. 1986; Chen et al. 1988). The occurrence of nematophorous graptolites immediately above the appearance of Cordylodus lindstromi has been a primary factor for continued consideration of the section as the CambrianOrdovician GSSP.

\section{Results}

One hundred and thirty core samples were collected from the Xiaoyangqiao Critical and Upper Sections in conjunction with a visit by the International Working Group on the Cambrian-Ordovician Boundary in August, 1986. Sampling intervals were less than one metre for most of the section and were tightly 
constrained to the local lithostratigraphy and previous sampling traverses. Sampling details are given in Table 1.

Carbonate whole rock isotopic analyses were performing using the conventional phosphoric acid method for generating $\mathrm{CO}_{2}$ gas (McCrea, 1950). Samples were measured on a Varian MAT250 gas ionization mass spectrometer; the results are listed in Table 1. Reproducibilities were better than $0.1 \%$ for $\delta^{13} \mathrm{C}$ and $0.2 \% \delta^{18} \mathrm{O}$. Results were determined using standards calibrated against NBS-19 $\quad\left(\delta^{13} \mathrm{C}=\right.$ $+1.92 \%, \delta^{18} \mathrm{O}=-2.20 \%$ vs. Peedee Belemnite; Coplen, Kendall \& Hopple, 1983). Standard dissolution times were $24 \mathrm{~h}$ at $28{ }^{\circ} \mathrm{C}$ for samples with < $10 \mathrm{~mol} \%$ dolomite, and $48 \mathrm{~h}$ for all others. A single sample containing $>40 \mathrm{~mol} \%$ dolomite was evacuated after $4 \mathrm{~h}$ dissolution to remove $\mathrm{CO}_{2}$ generated from the calcite fraction. Dolomite/total carbonate values were determined by X-ray diffraction after the method of Füchtbauer \& Goldschmidt (1965).

Carbon and oxygen isotope profiles from carbonate rocks are shown in Figure 2. $\delta^{13} \mathrm{C}$ values ranged between $-0.3 \%$ and $+1.3 \%$ (vs. PDB). The $\delta^{13} \mathrm{C}$ profile is marked by a sharp $0.7 \%$ rise at the base of Bed 8 , followed by a $1.5 \%$ drop through the next $15 \mathrm{~m}$, culminating at the base of Bed $13 \cdot \delta^{13} \mathrm{C}$ values show a small positive cycle between $-0.2 \%$ and $+0.3 \%$ throughout Bed 13 and Bed $14(5 \mathrm{~m})$, and then rise sharply by about $0.7 \%$ at the base of Bed 16 , followed by an interval of fairly stable $\delta^{13} \mathrm{C}$ with a broad lowering of $\delta^{13} \mathrm{C}$ near the base of the Cordylodus angulatus Zone.

Oxygen isotope values ranged between $\delta^{18} \mathrm{O}=$ $-11 \%$ and $-8 \%$ (vs. PDB). Although long-ranging trends in the $\delta^{18} \mathrm{O}$ profile were similar to those seen in $\delta^{13} \mathrm{C}$, changes in $\delta^{18} \mathrm{O}$ were not directly correlative with $\delta^{13} \mathrm{C}$ (Fig. 3) at the sample level, except for a tendency towards lower $\delta^{18} \mathrm{O}$ and $\delta^{13} \mathrm{C}$ values in mudstones and shales. The $\delta^{18} \mathrm{O}$ values are consistent with those from other Palaeozoic carbonate rocks (Wadleigh \& Veizer, 1992), and probably reflect exchange with meteoric or diagenetic fluids during shallow burial conditions (see Banner \& Hanson, 1990) rather than depositional values. Inferred temperatures based on the conodont alteration index noted above are compatible with this mechanism.

\section{Discussion}

The Black Mountain section in western Queensland, Australia provides an excellent basis for comparison of the Xiaoyangqiao results. The two sections were probably separated by no more than $1000 \mathrm{~m}$ at the end of the Cambrian (Burrett \& Stait, 1986; Scotese, 1987; Burrett, Long \& Stait, 1990; Kirschvink, 1992; Ripperdan \& Kirschvink, unpub. data). Deposition during the boundary interval was apparently continuous at Black Mountain (Druce, Shergold \& Radke,
1982), and detailed conodont, palaeomagnetic, and carbon isotope stratigraphies have been recently described (Nicoll \& Shergold, 1991; Shergold \& Nicoll, 1992; Ripperdan \& Kirschvink, 1992; Ripperdan et al. 1992).

Both sections display a rapid rise in $\delta^{13} \mathrm{C}$ near the FAD of Cordylodus proavus, followed by a rapid lowering of $\delta^{13} \mathrm{C}$ to a minimum at the base of the $H$. simplex Zone ( $\approx$ Cordylodus intermedius Zone) (Fig. 4). An overlying $1.5 \%$ positive $\delta^{13} \mathrm{C}$ cycle spans the $100 \mathrm{~m}$-thick $H$. simplex Zone at Black Mountain, whereas a smaller, poorly defined positive $\delta^{13} \mathrm{C}$ cycle encompassing the entire $C$. intermedius Zone occurs within only a $5 \mathrm{~m}$ interval in the Xiaoyangqiao section. Both profiles show subsequent sharp rises from these levels, with $\delta^{13} \mathrm{C}$ values stabilizing and then broadly declining towards the base of the Cordylodus angulatus Zone.

Despite their similarities, the sections have important differences at two key levels: within the lower Cordylodus proavus Zone, and within the lower Cordylodus lindstromi Zone. These differences are outlined below.

\section{4.a. Lower Cordylodus proavus Zone}

At Xiaoyangqiao, a discontinuity in the $\delta^{13} \mathrm{C}$ profile occurs within Bed 8 between samples XCS 40 and XCS 41 (Fig. 2). XCS 40 was taken from the same level as the first appearance datum (FAD) of Fryxellodontus inornatus. At Black Mountain, the lowest $F$. inornatus as found 35 metres below the maximum $\delta^{13} \mathrm{C}$ values within the Cordylodus proavus Zone (Fig. 4); at Xiaoyangqiao, the interval between the $\mathrm{FAD}$ of $F$. inornatus and maximum $\delta^{13} \mathrm{C}$ is less than 0.5 metres within Bed 8 .

Underlying strata with normal polarity at Xiaoyangqiao can be correlated to the F1+ normal polarity magnetozone within the upper Hispidodontus appressus Zone at Black Mountain. This alternative is favoured by comparisons with the last occurrence datum (LOD) of Proconodontus muelleri. At Black Mountain, the LOD of $P$. muelleri is above the top of the F1 + interval; at Xiaoyangqiao, the LOD of P. muelleri is in Bed 5, within the upper part of the $\mathrm{F}+$ interval (Chen et al. 1986, table 16, p. 102). Since the range of $P$. muelleri typically does not overlap the range of Fryxellodontus inornatus (Miller, 1988), and the F3 + magnetozone at Black Mountain is at the FAD of $F$. inornatus, it is unlikely that the F3+ magnetozone is correlative with the bulk of the $\mathrm{F}+$ zone at Xiaoyangqiao. It is possible that the Bed 7 portion of the $\mathrm{F}+$ magnetozone at Xiaoyangqiao is correlative to the F3+ magnetozone at Black Mountain, with strata equivalent to the intervening F2 - zone absent, but the lack of supporting $\delta^{13} \mathrm{C}$ data and a $1.7 \mathrm{~m}$ gap in the magnetic polarity profile make this only a speculative suggestion. 
Table 1. Sampling numbers, stratigraphic positions, carbon and oxygen isotope data, magnetic polarity interpretation, positions with respect to previous sampling traverses and important stratigraphic horizons

\begin{tabular}{|c|c|c|c|c|c|c|}
\hline Sample & $\mathrm{HT}(\mathrm{m})$ & $\delta^{18} \mathrm{C}$ & $\delta^{18} \mathrm{O}$ & Polarity & Location & Notes \\
\hline $\mathrm{XCS} 2$ & 0.4 & 0.51 & -9.67 & - & $0.1 \mathrm{~m}$ above $1-\mathrm{A}$ & \\
\hline $\operatorname{xCS} 6$ & 1.4 & 0.30 & -9.54 & - & at $1-C_{1}$ & \\
\hline $\mathrm{XCS} 7$ & 1.5 & 0.31 & -9.55 & normal & at $1-C_{2}$ & \\
\hline XCS 11 & 2.8 & 0.64 & -8.81 & - & $\mathrm{Cu}_{2}$ & \\
\hline XCS 12 & 3.0 & 0.58 & -8.80 & - & - & \\
\hline XCS 13 & 3.1 & 0.04 & -9.87 & - & at $1-\mathrm{E}$ & \\
\hline $\mathrm{XCS} 13 \mathrm{~A}$ & 3.4 & 0.52 & -8.99 & - & $0.1 \mathrm{~m}$ below $2-\mathrm{A}$ & \\
\hline XCS 14 & 4.4 & 0.48 & -9.46 & normal & at $2-\mathrm{B}$ & \\
\hline $\mathrm{XCS} 15$ & 4.6 & - & - & reversed & at $2-\mathrm{D}$ & \\
\hline XCS 16 & 4.6 & 0.69 & -8.93 & normal & at $2-\mathrm{E}$ & \\
\hline XCS 17 & 5.4 & - & - & normal & at $2-\mathrm{H}$ & \\
\hline XCS 18 & 5.6 & 0.40 & -9.16 & normal & - & \\
\hline XCS 19 & 5.8 & 0.57 & -8.99 & normal & $0.1 \mathrm{~m}$ above $2-\mathrm{I}$ & \\
\hline XCS 20 & 5.9 & - & - & normal & - & \\
\hline $\mathrm{XCS} 21$ & 6.3 & - & - & normal & - & \\
\hline XCS 22 & 6.4 & - & - & normal & at $3-2$ & \\
\hline XCS 23 & 6.6 & 0.44 & -8.84 & normal & midway $3-3,3-4$ & \\
\hline XCS 24 & 6.8 & 0.24 & -8.87 & - & at $3-\mathrm{A}_{1}$ & \\
\hline XCS 25 & 6.9 & 0.62 & -9.17 & normal & at $3-\mathrm{A}_{\text {? }}$ & \\
\hline XCS 26 & 7.3 & 0.50 & -9.15 & normal & at $3-C_{1}^{2}$ & \\
\hline XCS 27 & 7.3 & 0.66 & -8.86 & - & at $3-\mathrm{C}_{2}$ & \\
\hline XCS 28 & 7.4 & 0.53 & -9.28 & - & - & \\
\hline XCS 29 & 7.9 & 0.62 & -9.56 & normal & at $3-\mathrm{E}$ & \\
\hline XCS 30 & 8.3 & 0.39 & -9.68 & - & at $3-\mathrm{E}$ & \\
\hline XCS 31 & 8.3 & 0.26 & -9.13 & - & $0.1 \mathrm{~m}$ below $3-\mathrm{F}$ & \\
\hline XCS 32 & 8.6 & 0.52 & -9.16 & - & at $3-G$ & \\
\hline XCS 33 & 8.9 & 0.11 & -9.23 & - & $0.1 \mathrm{~m}$ above 5 & LOD Proconodontus muelleri \\
\hline XCS 36 & 9.6 & - & - & normal & - & \\
\hline XCS 38 & 10.7 & 0.73 & -8.86 & normal & $0.1 \mathrm{~m}$ below $7-\mathrm{B}$ & Above FAD Cordvlodus proavus \\
\hline XCS 39 & 11.4 & 0.72 & -8.88 & normal & at top of $7-B$ & \\
\hline XCS 40 & 11.7 & 0.52 & -8.44 & - & at $8-\mathrm{A}$ & FAD Fryxellodontus inornatus \\
\hline $\mathrm{XCS} 41$ & 12.2 & 1.25 & -8.70 & - & $0.2 \mathrm{~m}$ below $8-\mathrm{C}$ & \\
\hline XCS 42 & 12.6 & 1.30 & -8.55 & - & $0.2 \mathrm{~m}$ above $8-\mathrm{C}$ & \\
\hline XCS 43 & 13.0 & - & - & - & at top of $8-D$ & \\
\hline XCS 44 & 13.3 & 1.29 & -8.28 & - & - 5 & \\
\hline XCS 45 & 15.0 & 1.42 & -7.69 & - & near $9-4$ & \\
\hline XCS 47 & 15.8 & 0.80 & -9.32 & - & at $9-5$ & \\
\hline XCS 48 & 16.0 & 1.14 & -8.64 & - & at $9-6$ & \\
\hline XCS 49 & 16.6 & 1.11 & -8.58 & reversed & 0.1 below $9-8$ & \\
\hline XCS 50 & 16.9 & 1.16 & -8.35 & - & 0.1 above $9-9$ & \\
\hline XCS 51 & 17.3 & 0.97 & -8.76 & - & at $9-11$ & \\
\hline XCS 52 & 17.6 & 0.89 & -8.47 & reversed & - & \\
\hline XCS 53 & 17.9 & 0.96 & -8.31 & - & - & \\
\hline XCS 54 & 18.4 & 0.85 & -8.71 & reversed & at $9-12$ & \\
\hline XCS 55 & 18.8 & 1.05 & -8.84 & reversed & at $9-13$ & \\
\hline XCS 56 & 19.4 & 0.62 & -8.89 & reversed & at $9-\mathrm{A}_{2}$ & \\
\hline XCS 57 & 20.0 & 0.77 & -8.74 & reversed & at $9-\mathrm{A}_{4}$ & \\
\hline XCS 58 & 20.5 & 0.75 & -8.89 & reversed & at $9-B_{2}$ & \\
\hline XCS 59 & 20.9 & 0.71 & -8.69 & reversed & at $9-C_{2}$ & \\
\hline XCS 60 & 22.0 & 0.71 & -8.65 & - & at $9-\mathrm{D}_{2}^{2}$ & \\
\hline XCS 61 & 23.2 & - & - & reversed & $0.1 \mathrm{~m}$ below $9-\mathrm{E}_{2}$ & \\
\hline XCS 62 & 23.8 & - & - & reversed & - & \\
\hline XCS 63 & 24.5 & 0.33 & -8.78 & reversed & midway $10-3,10-4$ & \\
\hline XCS 64 & 25.2 & 0.29 & -9.01 & - & at $10-5$ & \\
\hline XCS 65 & 25.7 & -0.12 & -9.88 & reversed & - & \\
\hline XCS 68 & 27.2 & -0.08 & -10.23 & reversed & - & \\
\hline XCS 70 & 27.7 & -0.06 & -9.09 & reversed & at $10-\mathrm{A}_{5}$ & \\
\hline $\mathrm{XCS} 71$ & 28.0 & 0.32 & -8.71 & - & - & \\
\hline $\mathrm{XCS} 72$ & 28.8 & -0.13 & -9.24 & - & at $11-\mathrm{AO}_{2}$ & \\
\hline $\mathrm{XCS} 74$ & 29.0 & 0.24 & -9.23 & reversed & at $11-\mathrm{A}_{1}$ & $\begin{array}{l}\text { FAD Cordylodus intermedius; } \\
\text { Hirsutodontus simplex }\end{array}$ \\
\hline XCS 75 & 29.3 & 0.32 & -9.03 & - & $0.1 \mathrm{~m}$ below $11-\mathrm{A}_{3}$ & \\
\hline XCS 76 & 30.5 & 0.12 & -8.35 & - & at base of $11-\mathrm{B}$ & \\
\hline XCS 77 & 31.1 & 0.16 & -9.81 & reversed & at $12-2$ & \\
\hline XCS 78 & 31.7 & -0.11 & -10.74 & reversed & - & \\
\hline XCS 79 & 32.3 & 0.63 & -8.50 & reversed & in $13-\mathrm{F}$ & Above FAD Cordylodus lindstromi \\
\hline XCS 81 & 33.2 & - & - & reversed & at $13-\mathrm{J}$ & \\
\hline XCS 82 & 34.1 & - & - & normal & at $13-\mathrm{O}$ & FAD nematophorous graptolites \\
\hline XCS 83 & 34.6 & 0.70 & -9.34 & normal & at $14-1$ & \\
\hline XCS 85 & 35.4 & 0.59 & -9.45 & - & at $15-\mathrm{A}$ & \\
\hline XCS 86 & 36.1 & 0.61 & -9.52 & - & at $15-\mathrm{D}$ & \\
\hline
\end{tabular}


Table 1. (cont.)

\begin{tabular}{|c|c|c|c|c|c|c|}
\hline Sample & $\mathrm{HT}(\mathrm{m})$ & $\delta^{18} \mathrm{C}$ & $\delta^{18} \mathrm{O}$ & Polarity & Location & Notes \\
\hline XCS 87 & 36.5 & - & - & normal & at $16-2$ & \\
\hline XCS 88 & 36.9 & 0.34 & -10.02 & normal & in $17-\mathrm{A}$ & \\
\hline XCS 89 & 37.2 & - & - & normal & - & \\
\hline XCS 90 & 37.6 & 0.36 & -10.00 & normal & midway $17-\mathrm{D}, 17-\mathrm{E}$ & \\
\hline XCS 91 & 38.0 & 0.37 & -9.74 & - & $0.1 \mathrm{~m}$ below $17-\mathrm{F}$ & \\
\hline XCS 92 & 38.2 & 0.34 & -9.91 & - & $0.1 \mathrm{~m}$ above $17-\mathrm{F}$ & \\
\hline XCS 93 & 38.4 & 0.53 & -9.73 & - & at $17-\mathrm{G}$ & \\
\hline XCS 94 & 38.9 & 0.55 & -9.81 & - & at $17-\mathrm{I}$ & \\
\hline XCS 95 & 39.7 & 0.74 & -8.50 & normal & at $18-\mathrm{C}$ & \\
\hline XCS 96 & - & - & - & normal & - & \\
\hline XCS 97 & 40.3 & 0.52 & -10.13 & normal & $0.1 \mathrm{~m}$ above 20 & \\
\hline XCS 98 & 40.5 & 0.57 & -9.63 & normal & at 21 & \\
\hline XCS 99 & 41.0 & 0.69 & -8.36 & normal & at $22-\mathrm{F}$ & \\
\hline XCS 100 & 41.2 & 0.39 & -10.22 & normal & at $22-\mathrm{G}$ & \\
\hline XCS 101 & 41.6 & 0.74 & -9.13 & normal & $0.2 \mathrm{~m}$ above $23-\mathrm{B}$ & \\
\hline XCS 102 & 44.5 & 0.71 & -8.80 & normal & $0.2 \mathrm{~m}$ above $25-\mathrm{G}$ & \\
\hline XCS 103 & 44.8 & 0.38 & -9.66 & normal & $0.2 \mathrm{~m}$ below $25-\mathrm{H}$ & \\
\hline XCS 104 & 44.9 & 0.51 & -8.82 & normal & $0.3 \mathrm{~m}$ above $26-\mathrm{A}$ & \\
\hline XCS $105 \mathrm{~A}$ & 48.0 & 0.53 & -8.93 & - & - & \\
\hline XUS 106 & 49.0 & 0.70 & -9.46 & normal & - & \\
\hline XUS 107 & 49.4 & 0.95 & -9.20 & - & at $28-1$ & \\
\hline XUS 108 & 49.8 & 0.76 & -8.09 & - & at $28-3$ & \\
\hline XUS 109 & 50.2 & 0.75 & -7.99 & - & at $28-4$ & \\
\hline XUS 110 & 51.4 & 0.62 & -8.22 & normal & at $28-7$ & \\
\hline XUS 111 & 52.0 & 0.59 & -8.37 & normal & at $29-1_{2}$ & \\
\hline XUS 112 & 53.0 & 0.44 & -8.37 & normal & at $29-1_{4}^{2}$ & \\
\hline XUS 113 & 53.0 & 0.49 & -8.37 & normal & -4 & \\
\hline XUS 114 & 54.3 & 0.39 & -8.30 & - & midway $29-2,29-3$ & FAD Cordylodus angulatus \\
\hline XUS 115 & 55.9 & 0.24 & -8.76 & - & at $29-4$ & \\
\hline XUS 117 & 58.1 & 0.26 & -8.34 & - & - & \\
\hline XUS 118 & 60.4 & 0.02 & -8.53 & - & in $29-7$ & \\
\hline XUS 119 & 62.0 & 0.26 & -8.13 & - & in $30-1$ & \\
\hline XUS 120 & 65.2 & 0.38 & -8.27 & - & - & \\
\hline XUS 121 & 66.5 & -0.12 & -8.54 & - & - & \\
\hline XUS 122 & 69.6 & 0.38 & -8.19 & normal & in $30-3$ & \\
\hline XUS 123 & 71.3 & 0.18 & -8.55 & - & in $30-4$ & \\
\hline XUS 124 & 73.3 & 0.11 & -8.48 & normal & - & \\
\hline XUS 125 & 75.3 & 0.07 & -8.29 & - & in $31-1.5$ & FAD Chosonodina herfurthi \\
\hline XUS 126 & 78.4 & 0.14 & -8.24 & - & in $31-2.5$ & \\
\hline XUS 127 & 81.6 & -8.08 & -8.56 & reversed & in $31-4.5$ & \\
\hline XUS 128 & 83.4 & - & - & normal & - & \\
\hline
\end{tabular}

XCS - Xiaoyangqiao Critical Section; XUS - Xiaoyangqiao Upper Section. Locations are based on HDA sampling numbers given in Chen et al. $(1986,1988)$.

An alternative correlation would place the lower $12 \mathrm{~m}$ at Xiaoyangqiao entirely within the F3+ magnetozone, but this possibility is less favoured because (a) the F3 + magnetozone occurs within only one sample at Black Mountain, while the F+ magnetozone ranges through 16 at Xiaoyangqiao; (b) $\delta^{13} \mathrm{C}$ values at the F3+ level at Black Mountain are only $0.3 \%$ lower than the maximum value, while at Xiaoyangqiao the $\delta^{13} \mathrm{C}$ value of the underlying strata averages $\sim 0.7 \%$ lower than the maximum; and (c) the required overlapping of the ranges of Fryxellodontus inornatus, Cambrooistodus cambricus, and Proconodontus muelleri is incompatible with current understanding of North American conodont faunas through the boundary interval (Miller, 1988).

Based on the first correlation, the approximately $70 \mathrm{~m}$ of section found at Black Mountain between the top of the $\mathrm{F} 1+$ magnetozone and the $C$. proavus Zone $\delta^{13} \mathrm{C}$ maximum are represented by no more than $1.5 \mathrm{~m}$ of section at Xiaoyangqiao. If the speculative correlation of the F3+ interval to Bed 7 is correct, then virtually all of the Hispidodontus discretus Zone at Black Mountain is absent from the Xiaoyangqiao section, or is restricted to a $1.7 \mathrm{~m}$ interval from which palaeomagnetic information was not obtained. In the unlikely event that the alternative correlation is correct, then deposition would have been relatively undisrupted through the lower $12 \mathrm{~m}$ of the Xiaoyangqiao section.

Depositional breaks or condensed intervals near Beds 7 and 8 at Xiaoyangqiao may be directly correlated to stages of the Lange Ranch Eustatic Event, identified at various localities across the western United States, Australia, and North China (Miller, 1984, 1992; Nicoll et al. 1992). 


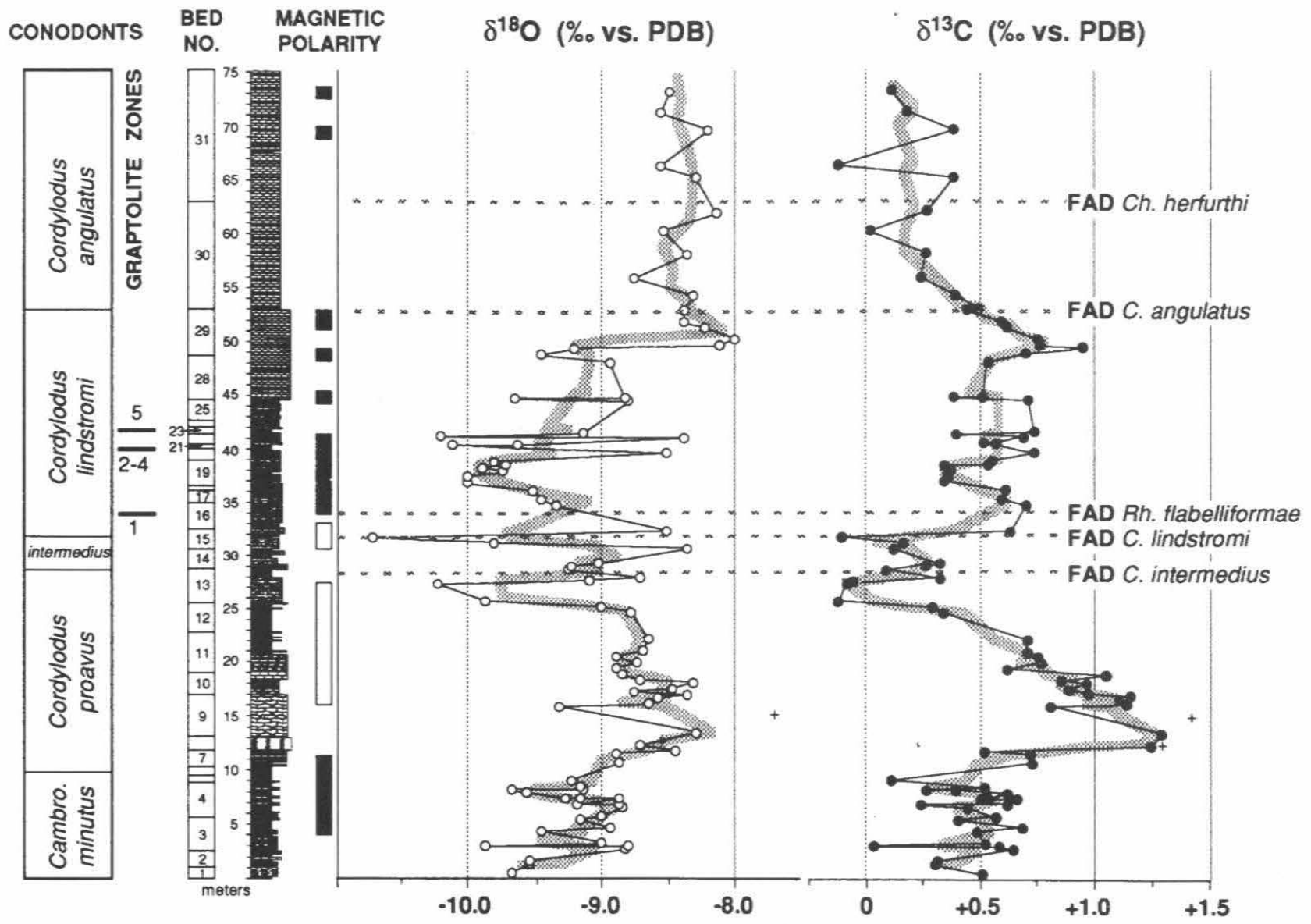

Figure 2. Carbon and oxygen isotope profiles from the Xiaoyangqiao Critical and Upper Sections (XCS, XUS) near Dayangcha. Lithostratigraphy and biostratigraphy from Chen et al. 1986, 1988); magnetic polarity profile from R. L. Ripperdan, unpub. Ph.D. thesis, Cal. Inst. Tech., 1990. FAD = first appearance datum. Plus symbols in both profiles represent samples with $>20 \mathrm{~mol} \%$ dolomite. The thick-shaped isotope profiles represent smoothing of all data by moving average (period $=3$ ), which minimizes non-systematic variability.

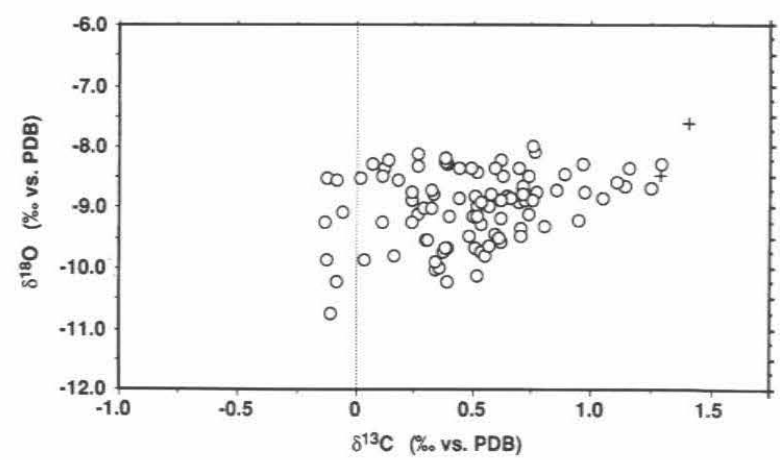

Figure $3 . \delta^{18} \mathrm{O}$ vs. $\delta^{13} \mathrm{C}$ from carbonate rocks at Xiaoyangqiao. Plus symbols represent samples with $>20 \mathrm{~mol} \%$ dolomite.

\section{4.b. Lower Cordylodus lindstromi Zone}

The first evidence of a magnetic polarity reversal at this level at Xiaoyangqiao was found at the same sampling horizon as the first appearance of nematophorous graptolites, in sample HDA 13-O of Bed 16 (sample XCS 82). Sampling resolution in this part of the section was high, and the polarity change is thus constrained to lie within $0.9 \mathrm{~m}$ of XCS 82 . The proximity of these two independent marker events raises suspicions that their superposition may be due to an underlying hiatus or a condensed interval.

Based on the conodont biostratigraphy, the polarity reversal at this level can be confidently correlated to the $\mathrm{H}+$ magnetozone at Black Mountain. Equating the base of magnetozone $\mathrm{H}+$ to sample XCS 82 requires that the lower $50 \mathrm{~m}$ of the Black Mountain Cordylodus lindstromi Zone be represented by only $2-3 \mathrm{~m}$ at Xiaoyangqiao. Furthermore, the highest $\delta^{13} \mathrm{C}$ values above the Cordylodus proavus Zone at Xiaoyangqiao do not approach the value of the maximum within that zone until well up into the $C$. lindstromi Zone; while at Black Mountain, $\delta^{13} \mathrm{C}$ maxima within the Cordylodus prolindstromi and Hirsutodontus simplex zones are virtually identical to that in the $C$. proavus Zone. This suggests that the $H$. simplex and $C$. prolindstromi zones may be poorly represented within the Xiaoyangqiao section, which is compatible with observations by some participants in the 1986 field excursion that Beds 14 and 15 are primarily turbidites and debris flows (J. Repetski, R. 


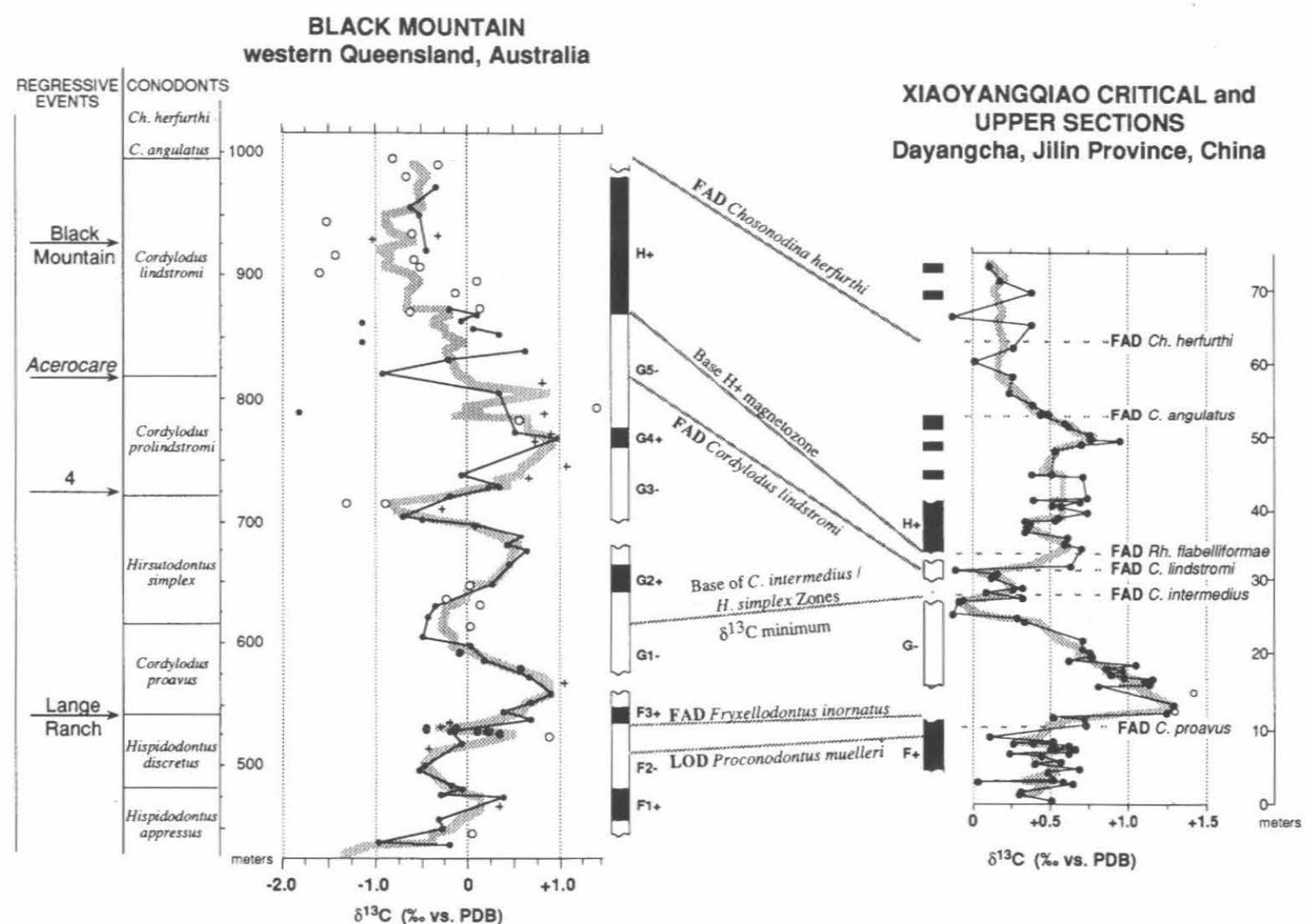

Figure 4. Correlation of $\delta^{13} \mathrm{C}$ and magnetic polarity profiles between Black Mountain, Australia (left) and Xiaoyangqiao. Black Mountain magnetic polarity results from Ripperdan \& Kirschvink (1992); carbon isotope results from Ripperdan et al. (1992). Biostratigraphy modified from Shergold \& Nicoll (1992) to accommodate stratigraphic positions of Ripperdan \& Kirschvink (1992); assemblage zone boundaries relative to sampling profile are precise. Regressive events from Nicoll et al. (1992) have been similarly modified.

Ethington, and M. Taylor, International Working Group on the Cambrian-Ordovician Boundary Circular 27, Appendix 3). Current investigations by M. Linström should further understanding of the sedimentology in this critical interval.

\section{4.c. Interpretations}

Our interpretation of the depositional history of the Xiaoyangqiao Critical and Upper sections is given in Fig. 5. The primary constraint used in constructing this diagram was that the correlation tie-lines used in Figure 4 be made parallel, or nearly so. This method highlights differential variations in depositional rates. It was assumed for purposes of comparison that the Black Mountain sequence preserves a continuous record of the Cambrian-Ordovician Boundary interval.

Deposition in the lower part of the Xiaoyangqiao Critical Section may have been disrupted at least twice, near Beds 5 to 7 and within Bed 8 , by both stages of the Lange Ranch Eustatic Event (LREE) (Miller, 1984, 1992; Nicoll et al. 1992). Based on the FAD of Cordylodus proavus, we interpret the F3+ magnetozone to be present in Bed 7, indicating that the entire F2 - magnetozone is absent from the Xiaoyangqiao section. A depositional break at this level is consistent with evidence from other localities for the first stage of the LREE. Another disruption is interpreted to occur within the lower part of Bed 8, immediately above the FAD of Fryxellodontus inornatus, and may be represented by a highly condensed interval rather than actual hiatus. In the western United States and at Wushan, North China, the FAD of $F$. inornatus is coincident with or immediately below shallowing-upwards sequences and disconformities marking the second regressive stage of the Lange Ranch Eustatic Event (Miller, 1984, 1992).

Deposition appears to have been nearly continuous through the upper portions of the Cordylodus proavus Zone. A steady decline in $\delta^{13} \mathrm{C}$ values is present in both sections, culminating at the base of the Hirsutodontus simplex and Cordylodus intermedius Zones.

A major change in deposition is suggested between Beds 13 and 16. The positive $\delta^{13} \mathrm{C}$ cycle found within the Hirsutodontus simplex Zone at Black Mountain, and the more poorly-defined interval of higher $\delta^{13} \mathrm{C}$ within the Cordylodus prolindstromi Zone, appear to have no firm correlatives within the Xiaoyangqiao section. The interval immediately above the FAD of 


\section{BLACK MOUNTAIN western Queensland, Australia}

\section{XIAOYANGQIAO CRITICAL and UPPER SECTIONS Dayangcha, Jilin Province, China}

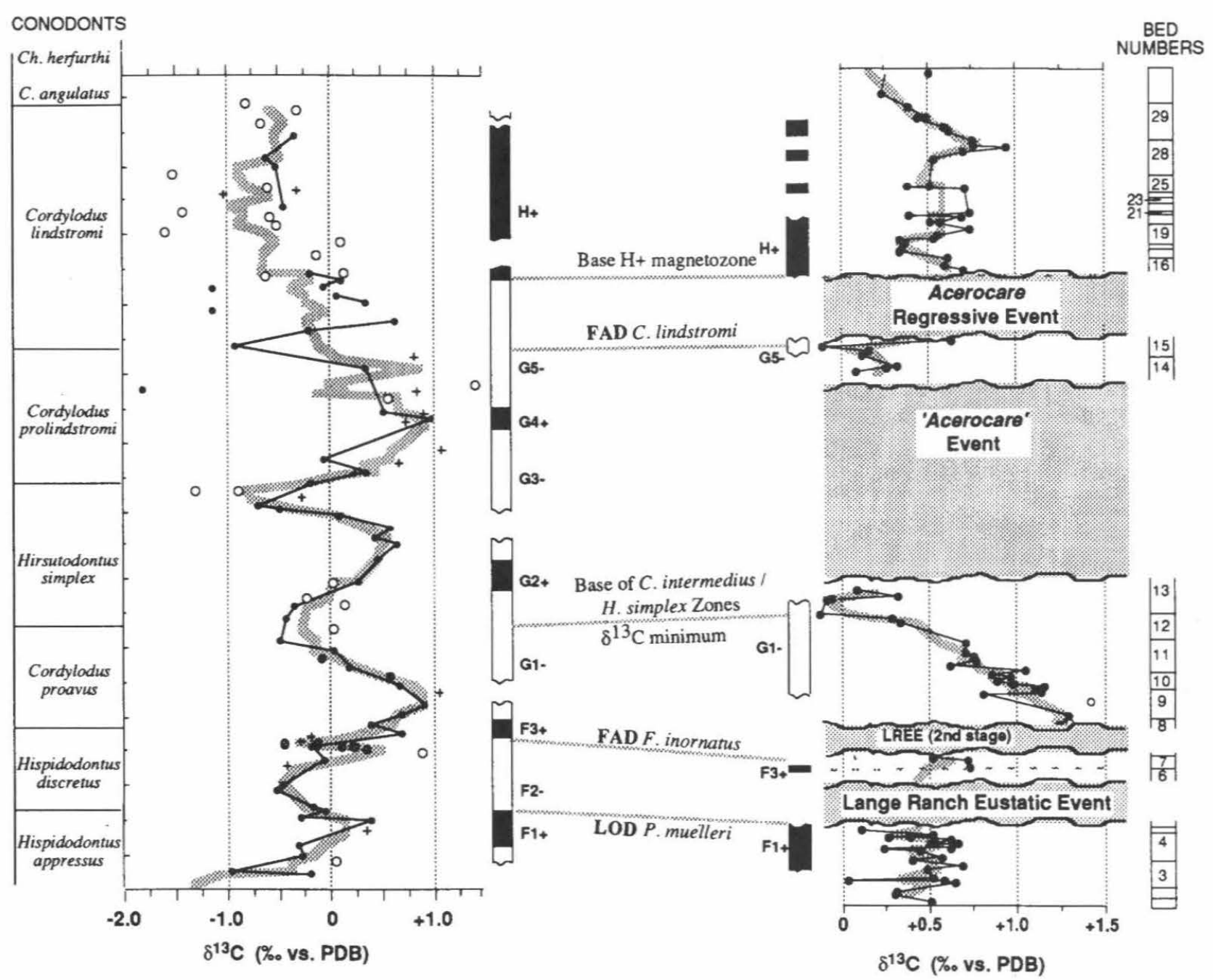

Figure 5. Interpretative diagram for the depositional history of the Xiaoyangqiao Critical Section. Acerocare Regressive Event sensu Nicoll et al. (1992); 'Acerocare' Event sensu Erdtmann (1986) (see text for discussion).

Cordylodus lindstromi may be directly correlatable to the Acerocare Regressive Event as defined in Australia (Nicoll et al. 1992). We interpret the extended interval of apparent non-deposition or condensation immediately below the base of the Cordylodus lindstromi Zone as correlative to the 'Acerocare Event' of Erdtmann (1986), which refers to a more prolonged period of sea level oscillations occurring throughout the Acerocare Zone in Scandinavia.

\section{Conclusions}

Correlations based on carbon isotope and magnetic polarity profiles from the Cambrian-Ordovician boundary section at Xiaoyangqiao, near Dayangcha, Jilin Province, China, and the contemporaneous section at Black Mountain, Australia indicate that at least two prominent periods of non-deposition or extremely slow deposition occurred during accumulation of the Xiaoyangqiao sequence. These can be correlated to regressive events identified in Australia, western North America, and Scandinavia, suggesting that sea level change strongly influenced deposition of the Xiaoyangqiao sequence. Despite the uncertain status of the first appearance datum of Cordylodus lindstromi, these major depositional breaks or condensed intervals occur very close to the proposed horizon for placement of the boundary GSSP. This suggests that the Xiaoyangqiao section may be unsuitable as a GSSP for the Cambrian-Ordovician boundary.

Acknowledgements. The authors wish to thank the Organizing Committees for the 1986 meeting of the CambrianOrdovician Boundary Working Group in Dayangcha for permission to work in their respective areas, and for their 
assistance in collecting samples. Laboratory and sampling assistance by A. Kobayashi-Kirschvink and R. Selnikov are gratefully acknowledged. J. L. Miller and two anonymous reviewers contributed helpful comments to improve this paper. This work was supported by NSF Grants EAR8721391 and PYI-8351370, by contributions from the Chevron Oil Field Research Company and the Arco Foundation, and by a Sir Charles Clore postdoctoral fellowship to the senior author. Weizmann Institute of Science Department of Environmental Science and Energy Research contribution 66; CIT Division of Geological and Planetary Sciences contribution 5176

\section{References}

Banner, J. L. \& Hanson, G. N. 1990. Calculations of simultaneous isotopic and trace element variations during water-rock interaction with applications to carbonate diagenesis. Geochimica et Cosmochimica Acta 54, 3123-37.

Burrett, C. \& Stait, B. 1986. China and southeast Asia as part of the Tethyan margin of Cambro-Ordovician Gondwanaland. In Shallow Tethys 2 (ed. K. G. McKenzie), pp. 65-77. International Symposium on Shallow Tethys 2, Wagga Wagga.

Burrett, C., Long, J., \& Stait, B. 1990. Early-Middle Paleozoic biogeography of Asian terranes derived from Gondwana. In Palaeozoic Palaeogeography and Biogeography (eds W. S. McKerrow and C. R. Scotese), pp. 163-174. Geological Society Memoirs 12, Bath.

Chen J.-Y., Erdtmann, B.-D., Gong W.-L., Li H.-M., Lin Y.-K., QIAN Y.-Y., TAO W.-C., WANG Y.-X., WANG Z.-Z., YANG J.-D., YIN L.-M. \& Zhang J.-M. 1986. Aspects of Cambrian-Ordovician Boundary in Dayangcha, China. Beijing: China Prospect Publishing House.

Chen J.-Y., Qian Y.-Y., Zhang J.-M., Lin Y.-K., YIN L.M., WANG Z.-H., WANG Z.-Z., YANG J.-D. \& WANG Y.-X. 1988. The recommended Cambrian-Ordovician boundary stratotype of the Xiaoyangqiao section (Dayangcha, Jilin Province), China. Geological Magazine 125, 415-44.

Coplen, T. B., Kendall, C., \& Hopple, J. 1983. Comparison of stable isotope reference samples. Nature $\mathbf{3 0 2}$, 236-8.

Druce, E. C., Shergold, J. H. \& Radke, B. M. 1982. A reassessment of the Cambrian-Ordovician boundary section at Black Mountain, western Queensland, Australia. In The Cambrian-Ordovician Boundary: Sections, Fossils Distributions, and Correlations (eds M. G. Bassett and W. T. Dean), pp. 193-209. National Museum of Wales, Geological Series 3, Cardiff.

Epstein, A. G., Epstein, J. B. \& Harris, L. D. 1977. Conodont color alteration - an index of organic metamorphism. U.S. Geological Survey Professional Paper no. 995,27 pp.

ERdtmann, B.-D. 1986. Early Ordovician eustatic cycles and their bearing on punctuations in early nematophorid (planktic) graptolite evolution. Lecture Notes in Earth Sciences 8, 139-52.

FüChtBauer, H. \& GoldschmidT, H. 1965. Beziehungen zwischen Calciumgehalt und Bildungsbedingungen der Dolomite. Geologische Rundschau 55, 29-40.

Harland, W. B., Armstrong, R. L., Cox, A. V., Craig, L. E., Sмiтн, A. G. \& Sмiтн, D. G. 1990. A Geologic Time Scale. Cambridge: Cambridge University Press.
Harrison, C. G. A. \& Somayajulu, B. L. K. 1966. Behaviour of the Earth's magnetic field during a reversal. Nature 212, 1193-5.

Holland, H. D. 1978. The Chemistry of the Atmosphere and Oceans. New York: John Wiley \& Sons.

KirschVinK, J. L. 1992. A paleogeographic model for Vendian and Cambrian time. In The Proterozoic Biosphere: A Multidisciplinary study (eds J. W. Schopf, C. Klein and D. Des Maris), pp. 567-81. Cambridge University Press.

KumP, L. R. \& Garrels, R. M. 1986. Modeling atmospheric $\mathrm{O}_{2}$ in the global sedimentary redox cycle. American Journal of Science 286, 337-60.

Magaritz, M. 1983. Carbon and oxygen isotope composition of recent and ancient coated grains. In Coated Grains (ed. T. M. Peryt), pp. 27-37. Berlin: SpringerVerlag.

Magaritz, M. 1989. ${ }^{13} \mathrm{C}$ minima follow extinction events: A clue to faunal radiation. Geology 17, 337-40.

Margolis, S. V., Mount, J. F., Doehne, E., Showers, W. \& WARD, P. 1987. The Cretaceous/Tertiary boundary carbon and oxygen isotope stratigraphy, diagenesis, and paleoceanography at Zumaya, Spain. Paleoceanography 2, 361-77.

MCCREA, J. M. 1950. On the isotopic chemistry of carbonate and a paleo-temperature scale. Journal of Chemical Physics 18, 849-57.

Miller, J. F. 1984. Cambrian and earliest Ordovician conodont evolution, biofacies, and provincialism. In Conodont Biofacies and Provincialism (ed. D. L. Clark), pp. 43-68. Geological Society of America Special Paper no 196.

Miller, J. F. 1988. Conodonts as biostratigraphic tools for redefinition and correlation of the CambrianOrdovician boundary. Geological Magazine 125, 349-62.

Miller, J. F. 1992. The Lange Ranch Eustatic Event: A regressive-transgressive couplet near the base of the Ordovician System. In Global Perspectives on Ordovician Geology (eds B. Webby and J. R. Laurie), pp. 395-407. Rotterdam: Balkema.

NiCOLL, R. S. 1990. The genus Cordylodus and a latest Cambrian-earliest Ordovician conodont biostratigraphy. Bureau of Mineral Resources Journal of Australian Geology and Geophysics 11, 529-58.

NiCOLL, R. S. 1991. Differentiation of Late Cambrian-Early Ordovician species of Cordylodus (Conodonta) with biapical basal cavities. Bureau of Mineral Resources Journal of Australian Geology and Geophysics 12, 223-44.

NiCOLL, R. S. 1992. Evolution of the conodont genus Cordylodus and the Cambrian-Ordovician boundary. In Global Perspectives on Ordovician Geology (eds B. Webby and J. R. Laurie), pp. 93-103. Rotterdam: Balkema.

Nicoll, R. S. \& Shergold, J. H. 1991. Revised Late Cambrian (pre-Payntonian-Datsonian) conodont biostratigraphy at Black Mountain, Georgina Basin, western Queensland, Australia. Bureau of Mineral Resources Journal of Australian Geology and Geophysics 12, 93-118.

Nicoll, R. S., Laurie, J. R., Shergold, J. H. \& Nielson, A. T. 1992. Preliminary correlation of latest Cambrian to Early Ordovician sea level events in Australia and Scandinavia. In Global Perspectives on Ordovician 
Geology (eds B. Webby and J. R. Laurie), pp. 381-94. Rotterdam: Balkema.

OpdyKe, N. D., KeNT, D. V. \& LowrIE, W. 1973. Details of magnetic polarity transitions recorded in a high deposition rate deep-sea core. Earth and Planetary Science Letters 20, 315-24.

RIPPERDAN, R. L. \& KIRSCHVINK, J. L. 1992. Paleomagnetic results from the Cambrian-Ordovician boundary section at Black Mountain, Georgina Basin, western Queensland, Australia. In Global Perspectives on Ordovician Geology (eds B. Webby and J. R. Laurie), pp. 93-103. Rotterdam; Balkema.

Ripperdan, R. L., Magaritz, M., Nicoll, R. S. \& SHERGOLD, J. H. 1992. Simultaneous changes in carbon isotopes, sea level, and conodont biozones within the Cambrian-Ordovician boundary interval at Black Mountain, Australia. Geology 20, 1039-42.

SCOTESE, C. R. 1987. Plate tectonic development of the
Circum-Pacific (Panthallasic Ocean) during the Early Paleozic. In Circum-Pacific Orogenic Belts and the Evolution of the Pacific Ocean Basin (eds J. W. Monger and J. Francheteau), pp. 49-57. American Geophysical Union Geodynamics Series no 18.

SHergold, J. H. \& Nicoll, R. S. 1992. Revised CambrianOrdovician boundary biostratigraphy, Black Mountain, western Queensland. In Global Perspectives on Ordovician Geology (eds B. Webby and J. R. Laurie), pp. 81-92. Rotterdam: Balkema.

Wadleigh, M. A. \& Veizer, J. 1992. ${ }^{18} \mathrm{O} /{ }^{16} \mathrm{O}$ and ${ }^{13} \mathrm{C} /{ }^{12} \mathrm{C}$ in lower Paleozoic articulate brachiopods: Implications for the isotopic composition of seawater. Geochimica et Cosmochimica Acta 56, 431-43.

ZAChOS, J. C. \& ARTHUR, M. A. 1986. Paleoceanography of the Cretaceous/Tertiary boundary event; inferences from stable isotopic and other data. Paleoceanography 1, 5-26. 